\title{
Modulation of doxorubicin cytotoxicity by resveratrol in a human breast cancer cell line
}

\author{
Abdel-Moneim M Osman ${ }^{1 *}$, Hadeel M Bayoumi ${ }^{1}$, Sameer E Al-Harthi ${ }^{1}$, Zoheir A Damanhouri ${ }^{1}$ \\ and Mohamed F EIShal ${ }^{2}$
}

\begin{abstract}
Background: Breast cancer is the most common cancer in the Arab world and it ranked first among Saudi females. Doxorubicin (DOX), an anthracycline antibiotic is one of the most effective anticancer agents used to treat breast cancer. chronic cardiotoxicity is a major limiting factor of the use of doxorubicin. Therefore, our study was designed to assess the role of a natural product resveratrol (RSVL) on sensitization of human breast cancer cells (MCF-7) to the action of DOX in an attempt to minimize doxorubicin effective dose and thereby its side effects.
\end{abstract}

Methods: Human breast cancer cell line MCF-7, was used in this study. Cytotoxic activity of DOX was determined using (sulforhodamine) SRB method. Apoptotic cells were quantified after treatment by annexin V-FITC- propidium iodide (PI) double staining using flow-cytometer. Cell cycle disturbance and doxorubicin uptake were determined after RSVL or DOX treatment.

Results: Treatment of MCF-7 cells with $15 \mu \mathrm{g} / \mathrm{ml} \mathrm{RSVL}$ either simultaneously or $24 \mathrm{~h}$ before DOX increased the cytotoxicity of DOX, with IC50 were 0.056 and $0.035 \mu \mathrm{g} / \mathrm{ml}$, respectively compared to DOX alone IC50 (0.417 $\mu \mathrm{g} / \mathrm{ml})$. Moreover, flow cytometric analysis of the MCF-7 cells treated simultaneously with DOX $(0.5 \mu \mathrm{g} / \mathrm{ml})$ and RSVL showed enhanced arrest of the cells in $G_{0}(80 \%)$. On the other hand, when RSVL is given $24 \mathrm{~h}$ before DOX although there was more increased in the cytotoxic effect of DOX against the growth of the cells, however, there was decreased in percentage arrest of cells in $G_{0}$, less inhibition of DOX-induced apoptosis and reduced DOX cellular uptake into the cells.

Conclusion: RSVL treatment increased the cytotoxic activity of DOX against the growth of human breast cancer cells when given either simultaneously or $24 \mathrm{~h}$ before DOX.

Keywords: Doxorubicin, Resveratrol, Breast cancer cell line

\section{Introduction}

Breast cancer is the leading cause of death in women worldwide and it is the most common cancer in the Arab world. It affects women at an early age compared with women in western countries [1]. Doxorubicin (DOX), an anthracycline antibiotic is among the most effective anticancer agents used to treat breast cancer [2]. It exerts its cytotoxic effect by intercalating between DNA base pairs on the double helix and inhibiting topoisomerase II (TOPO-II), the enzyme responsible for DNA helix

\footnotetext{
* Correspondence: moneimosman@hotmail.com

'Department of Pharmacology, Faculty of Medicine, King Abdul-Aziz University, Jeddah, Saudi Arabia

Full list of author information is available at the end of the article
}

conformation and stability. Unfortunately, chronic cardiotoxicity including development of a cardiomyopathy is a major limiting factor of the chemotherapeutic use of doxorubicin [3]. In an attempt to minimize DOX effective chemotherapeutic dose and thereby its side effects, a variety of approaches have been Investigated. One of them is the search for natural compounds with chemopreventive or anticancer properties that can be used in combination with doxorubicin. Resveratrol (RSVL) (trans - 3, 5, 4- trihydroxystilbene) is a naturaly occurring poly-phenolic compound found primarily in root extracts of the oriental plant Polygonum cuspidatum and many other plant species [4]. It is highly abundant in skins of red grapes and moderately abundant in peanuts and blueberries [4]. It has recently been discovered that it 
has many beneficial effects in different biological systems, which include anti-inflammatory, antioxidant, anti-neoplastic, anti-carcinogenic, anti-tumorigenic, cardioprotective, neuroprotective, anti-aging and antiviral effects [4]. Its potential chemopreventive and chemotherapeutic activities have been demonstrated in all three stages of carcinogenesis (initiation, promotion, and progression) [5]. Resveratrol exhibits anticancer properties in a wide variety of tumor cells, including breast cancer cells [6]. The growth-inhibitory effect of RSVL is mediated through different mechanisms [7]. Therefore this study was aimed to explore whether the natural product resveratrol could enhance the cytotoxic effect of DOX against the growth of human breast cancer cell line (MCF-7 cell line). We investigated the possible mechanisms of interaction between DOX and RSVL regarding DOX cytotoxicity, apoptosis induction, cellular uptake and cell cycle progression of breast cancer cells in presence and absence of RSVL.

\section{Materials and methods}

\section{Drugs and chemicals}

DOX hydrochloride and RSVL were purchased from Sigma Aldrich (St. Louis, Mo, USA). The stock solutions of both drugs were dissolved in phosphate buffered saline (PBS) and preserved at $-20^{\circ} \mathrm{C}$. The solution was diluted in Dullbecco's modified Eagles medium (DMEM) or PBS immediately before each experiment to the desired final concentrations. Dullbecco's modified eagles medium (DMEM), Trypsin/EDTA, Phosphate buffered saline (PBS), Penicillin G and Steptomycin antibiotics, Acetic acid, Trizma base, SulphoRhodamine- B (SRB), Propidium Iodide (PI) and Annexin V-FITC apoptosis detection kit were purchased from Sigma Aldrich Co.

\section{Cells and cell cultures}

Human breast cancer cell line MCF-7, was used in this study. It was obtained from National Cancer Institute, Cairo University, Egypt.

The adherent cells were grown as "monolayer culture" in DMEM supplemented with Penicillin (100 IU/ml), Streptomycin $(100 \mu \mathrm{g} / \mathrm{ml})$ and $10 \%$ Fetal bovine serum. Cells were cultured at $37^{\circ} \mathrm{C}$ in a humidified $5 \% \mathrm{CO}_{2}$ atmosphere and were passaged every 4-5 days.

\section{Methods}

\section{Assessment of cytotoxic activity}

Cytotoxicity was determined using (sulforhodamine) SRB method as previously described by Skehan et al. [8]. Cells were seeded in 96 well microtiter plates at a concentration of $30 \times$ cells/well in DMEM supplemented medium. After $24 \mathrm{~h}$, cells were incubated for additional $48 \mathrm{~h}$ with various concentrations of DOX and RSVL in the following ranges: $0.0312-5 \mu \mathrm{g} / \mathrm{ml}$ for DOX and $15 \mu \mathrm{g} / \mathrm{ml}$ for RSVL. Drugs were added either in a simultaneous or sequential manner. In sequential treatment, the cells were pretreated with RSVL for $24 \mathrm{~h}$, and then followed by DOX for further $48 \mathrm{~h}$. Cells were fixed in situ by adding $50 \mu \mathrm{L}$ of cold $50 \%$ TCA for $1 \mathrm{~h}$ at $4^{\circ} \mathrm{C}$. the supernatant is then discarded, and the wells were washed five times with distilled water, air dried, stained for $30 \mathrm{~min}$ at room temperature with $0.4 \%$ SRB dissolved in 1\% acetic acid and then washed four times with $1 \%$ acetic acid. The plates were air dried and the dye was solubilized with $100 \mu \mathrm{l} /$ well of $10 \mathrm{mM}$ Tris base (PH 10.5) for $10 \mathrm{~min}$. The optical density (OD) was obtained using ELx808 Absorbance Microplate Reader obtained from BioTek Instruments,Inc (Winooski,VT, U.S.A.) at wavelength of (490-530 nm).

\section{Surviving fraction

$$
=\frac{\text { Optical density oftreated cells }}{\text { Optical density of untreated control cells }}
$$

IC50 (the concentration of DOX necessary to produce $50 \%$ inhibition of cell growth) was calculated from linear equation of the survival fraction curve.

$$
\mathrm{Y}=\mathrm{mX}+\mathrm{b}
$$

Where:

$\mathbf{Y}=0.5$ (the surviving fraction when there is a $50 \%$ inhibition of cell growth).

$\mathbf{m}=$ the slope.

$\mathbf{X}=$ dose of DOX induces $50 \%$ inhibition.

$\mathbf{b}=$ the $\mathrm{y}$-intercept.

\section{Flow-cytometric assay of apoptosis}

Apoptotic cells were quantified by Annexin V-FITCPropidium iodide (PI) double staining, using an Annexin V-FITC apoptosis detection kit according to the method of Van Engeland et al. [9]. Cells were seeded in 12-well plates at cell density of $6-8 \times$ cells/well in DMEM supplemented medium. Twenty four hours later, cells were incubated for additional $48 \mathrm{~h}$ with $15 \mu \mathrm{g} / \mathrm{ml} \mathrm{RSVL}$ and various concentrations of DOX in the following range: $0.25-0.5 \mu \mathrm{g} / \mathrm{ml}$. Drugs were added in a simultaneous or sequential manner. In sequential treatment, the cells were pretreated with RSVL for $24 \mathrm{~h}$, and then followed by DOX for additional $48 \mathrm{~h}$. Cell medium was then removed and the wells were washed with PBS, then the cells were harvested with trypsin/EDTA. Cells were washed once with PBS following trypsinization, resuspended in $1 \mathrm{ml}$ of Binding Buffer. Annexin V FITC Conjugate were added to the cells according to manufacturer's instructions for $10 \mathrm{~min}$ at room temperature while protected from light. Fluorescence of the cells was read immediately by flow cytometer (NAVIOS Beckman Coulter, U.S.A.). 


\section{Cell cycle analysis}

Cells were plated in 12-well plates at cell density of 6 $8 \times 10^{5}$ cells/well in DMEM supplemented medium. Twenty four hours later, cells were incubated for additional $48 \mathrm{~h}$ with $15 \mu \mathrm{g} / \mathrm{ml} \mathrm{RSVL}$ and a various concentrations of DOX in the following range: $0.125-0.5$ $\mu \mathrm{g} /$. Drugs were added in a simultaneous or sequential manner. In sequential treatment, the cells were pretreated with RSVL for $24 \mathrm{~h}$, and then followed by DOX for $48 \mathrm{~h}$. Cell medium was then removed and the wells were washed once with PBS. Cell cycle analysis was performed according to the method of Pozarowski and Darzynkiewicz, [10].

The cells were harvested with trypsin/EDTA, washed once with PBS and then resuspended in $0.5 \mathrm{ml}$ of $0.05 \%$ Triton X-100 for $10 \mathrm{~min}$ at room temperature. Stai ning of cellular DNA was performed by adding $1 \mathrm{ml}$ of $50 \mu \mathrm{g} / \mathrm{mL}$ PI to each cell suspension for $20 \mathrm{~min}$ at room temperature. Cell cycle analysis was performed by using flow cytometer (Becton Dicknoson (BD) FACSCalbur, USA).

\section{Assessment of doxorubicin cellular accumulation}

DOX cellular accumulation assessment in MCF-7 cells was performed using spectrofluorometer (F-2000 Fluorescence spectrophotometer Hitachi, Japan) according to the method of Kitagawa et al. [11]. DOX fluorescence intensity was measured at excitation and emission wavelengths of $\lambda$ ex $=496 \mathrm{~nm}$ and $\lambda$ em $=592 \mathrm{~nm}$, respectively to determine DOX concentration.

DOX cellular accumulation ratio

$$
=\frac{\text { DOX concentration in RSVL treated cells }}{\text { DOX concentration in cells treated with DOX alone }}
$$

\section{Statistical analysis}

Statistical analysis was performed using SPSS (statistical package of social sciences, version 16). One way analysis of variance (ANOVA) followed by least significant difference (LSD) for post hoc analysis, was used for multiple comparisons. Statistical significance was acceptable to a level of $\mathrm{p}<0.05$.

\section{Results}

Effect of RSVL treatment on the cytotoxic activity of DOX Cytotoxicity was expressed as the percentage of surviving fraction compared with untreated control cells (Tables 1 and 2). Treatment with DOX alone showed IC50 (the concentration necessary to produce $50 \%$ inhibition of cell growth) value of $0.417 \mu \mathrm{g} / \mathrm{ml}$. Simultaneous addition of $15 \mu \mathrm{g} / \mathrm{ml}$ RSVL with or $24 \mathrm{~h}$ before DOX was found to sensitize MCF-7 cells to the cytotoxic effect of DOX., IC50 were $0.056 \mu \mathrm{g} / \mathrm{ml}$ and $0.035 \mu \mathrm{g} / \mathrm{ml}$, respectively,
Table 1 Effect of DOX and RSVL (15 ug/ml) on the growth of MCF-7 cells

\begin{tabular}{lccc}
\hline & \multicolumn{3}{c}{ Surviving Fraction } \\
\cline { 2 - 4 } $\begin{array}{l}\text { DOX } \\
\begin{array}{l}\text { Concentration } \\
(\boldsymbol{\mu g} / \mathrm{ml})\end{array}\end{array}$ & DOX & $\begin{array}{c}\text { DOX+RSVL } \\
\text { Simultaneously }\end{array}$ & $\begin{array}{c}\text { DOX+RSVLRSVL } \\
\mathbf{2 4 h} \text { before }\end{array}$ \\
\hline $\mathbf{0 . 0 6 2 5}$ & $0.97 \pm 0.17$ & $0.10^{\mathbf{a}} \pm 0.013$ & $0.173^{\mathrm{a}} \pm 0.03$ \\
\hline $\mathbf{0 . 2 5}$ & $0.92 \pm 0.112$ & $0.091^{\mathrm{a}} \pm 0.018$ & $0.124^{\mathbf{a}} \pm 0.006$ \\
\hline $\mathbf{0 . 5}$ & $0.29 \pm 0.061$ & $0.089^{\mathbf{a}} \pm 0.034$ & $0.047^{\mathrm{a}, \mathrm{b}} \pm 0.003$
\end{tabular}

Each data is the mean \pm S.E.M of two experiments each one in duplicate. ${ }^{a}$ Significantly different from DOX at P-value $<0.05$.

b Significantly different from simultaneous DOX+RSVL at P-value $<0.01$.

which were significantly different from DOX alone. At the same time RSVL 24 before DOX showed IC50 value significantly different from DOX+RESVL supplied simultaneously.

Effect of RSVL and DOX treatment on apoptosis induction Apoptosis was determined by flow cytometry in MCF-7 cells that have been stained with FITC-annexin V and PI. Percentages of cells in each quadrant in Figures 1 and 2 are representative of: (C1) necrosis, (C2) late apoptosis, (C3) live cells, and (C4) early apoptosis. Figure 1 shows control MCF-7 cells (A), cells treated with $15 \mu \mathrm{g} / \mathrm{ml}$ RSVL (B) and cells treated with $0.5 \mu \mathrm{g} / \mathrm{ml}$ DOX alone $(\mathrm{C})$ or in the presence of $15 \mu \mathrm{g} / \mathrm{ml} \mathrm{RSVL}$ given simultaneously with $0.5 \mu \mathrm{g} / \mathrm{ml}$ DOX (D) or $24 \mathrm{~h}$ before it (E). Figure 2 showed cells treated with 0.25 $\mu \mathrm{g} / \mathrm{ml}$ DOX alone $(\mathrm{F})$ or in the presence of $15 \mu \mathrm{g} / \mathrm{ml}$ RSVL given simultaneously with $0.25 \mu \mathrm{g} / \mathrm{ml}$ DOX (G) or $24 \mathrm{~h}$ before it $(\mathrm{H})$.

The percentage of early apoptotic cells (Annexin Vpositive cells) were dramatically increased after treatment with DOX or DOX + RSVL in comparison to the control cells (1.3\% early apoptotic cells). Treatment with $0.25 \mu \mathrm{g} / \mathrm{ml}$ DOX showed $76.1 \%$ of early apoptotic cells. While combination treatment of $0.25 \mu \mathrm{g} / \mathrm{ml}$ DOX with $15 \mu \mathrm{g} / \mathrm{ml}$ RSVL simultaneously or RSVL $24 \mathrm{~h}$ before DOX showed $91.2 \%$, and $76.1 \%$ of early apoptotic cells, respectively (Figure 3).

Table 2 Effect of DOX and/or RSVL on the growth of MCF-7 cells

\begin{tabular}{lc}
\hline Treatment & IC50 $(\boldsymbol{\mu g} / \mathrm{ml})$ \\
\hline DOX & $0.417 \pm 0.107$ \\
\hline $\begin{array}{l}\text { DOX + RSVL (15 } \boldsymbol{\mu g} / \mathrm{ml}) \\
\text { (supplied simultaneously) }\end{array}$ & $0.056^{\mathrm{a}} \pm 0.026$ \\
\hline $\begin{array}{l}\text { DOX + RSVL (15 } \boldsymbol{\mu g} / \mathrm{ml}) \\
\text { (RSVL supplied 24 h before DOX) }\end{array}$ & $0.035^{\mathbf{a}, \mathrm{b}} \pm 0.016$ \\
\hline
\end{tabular}

IC50: the concentration of DOX necessary to produce $50 \%$ inhibition of cell growth.

a Significantly different from DOX at P-value $<0.05$.

${ }^{\mathrm{b}}$ Significantly different from DOX+ RSVL (Simultaneously) at P-value $<0.05$. 


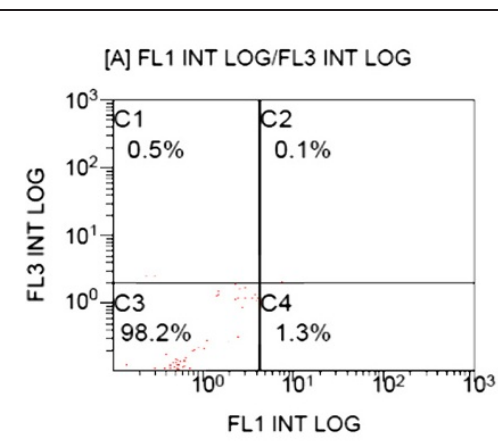

(A)

[A] FL1 INT LOG/FL3 INT LOG

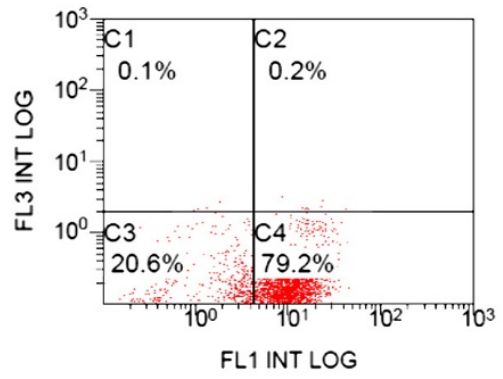

(C)

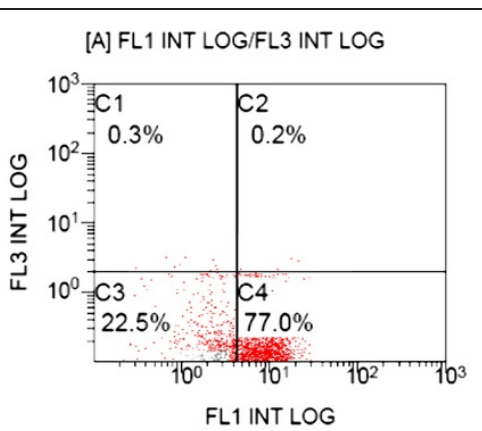

(B)

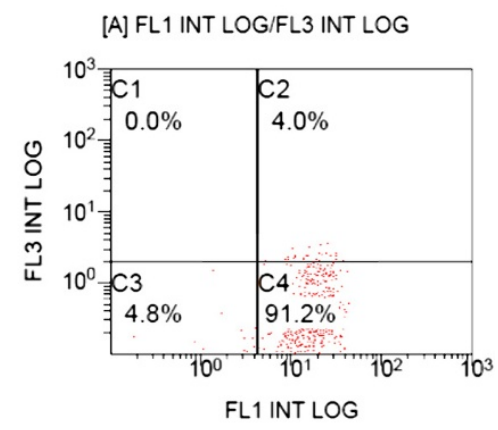

(D)

[A] FL1 INT LOG/FL3 INT LOG

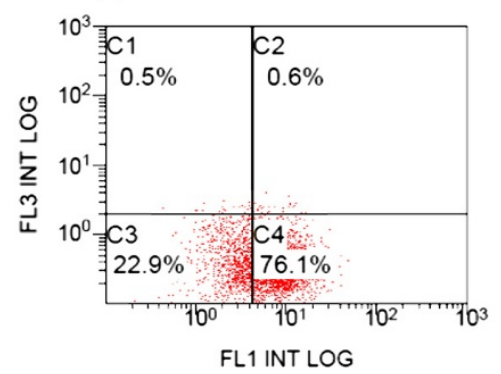

(E)

Figure 1 Effect of DOX and/or RSVL on apoptosis induction in MCF-7 cells. Apoptosis was analyzed after 48 h of exposure to drugs by staining with propidium iodide (PI, y-axis) and annexin- FITC (X-axis). (A) control, (B) cells treated with $15 \mu \mathrm{g} / \mathrm{ml} \mathrm{RSVL,} \mathrm{(C)} \mathrm{cells} \mathrm{treated} \mathrm{with}$ $0.25 \mu \mathrm{g} / \mathrm{ml}$ DOX, (D) cells treated with $0.25 \mu \mathrm{g} / \mathrm{ml}$ DOX and RSVL $15 \mu \mathrm{g} / \mathrm{ml}$ in simultaneous manner, (E) cells treated with $0.25 \mu \mathrm{g} / \mathrm{ml}$ DOX and RSVL $15 \mu \mathrm{g} / \mathrm{ml}$ given $24 \mathrm{~h}$ before DOX. The percentage of cells in each quadrant are indicated (C1: necrosis, C2: late apoptosis, C3: live cells, C4: early apoptosis). The experiment was repeated twice each one in duplicate.

\section{Effect of RSVL and/or DOX treatment on cycle phase progression of MCF-7}

Treatment with different concentrations of DOX $(0.125$, 0.25 and $0.5 \mu \mathrm{g} / \mathrm{ml}$ ), showed a preferential block of MCF7 cells in S phase (data not shown). DOX concentration increased cell accumulation in $\mathrm{S}$ phase to $8.41 \%$ and $10.9 \%$ at dose level of 0.25 and $0.5 \mathrm{ug} / \mathrm{ml}$,respectively (Figure 3) compared with cells in $G_{1}$ phase. Treatment with $15 \mu \mathrm{g} / \mathrm{ml}$ RSVL showed arrest of cells in $\mathrm{G}_{0}$ and $\mathrm{S}$ phases compared with $\mathrm{G}_{1}$ phase cells $44.53 \%$ and $8.82 \%$, respectively (Figure 4).

Combination treatment of DOX $0.25 \mu \mathrm{g} / \mathrm{ml}$ with $15 \mu \mathrm{g} / \mathrm{ml}$ RSVL simultaneously showed a huge increase in the percentages of cells in $G_{0}$ phase in comparison with $G_{1}$ phase cells. The cell accumulation percentage at $\mathrm{G}_{0}$ phase was $79.77 \%$ when treated with $0.25 \mu \mathrm{g} / \mathrm{ml}$ DOX given simultaneously with $15 \mu \mathrm{g} / \mathrm{ml}$ RSVL (Figure 4). Combination treatment of the same concentration of 


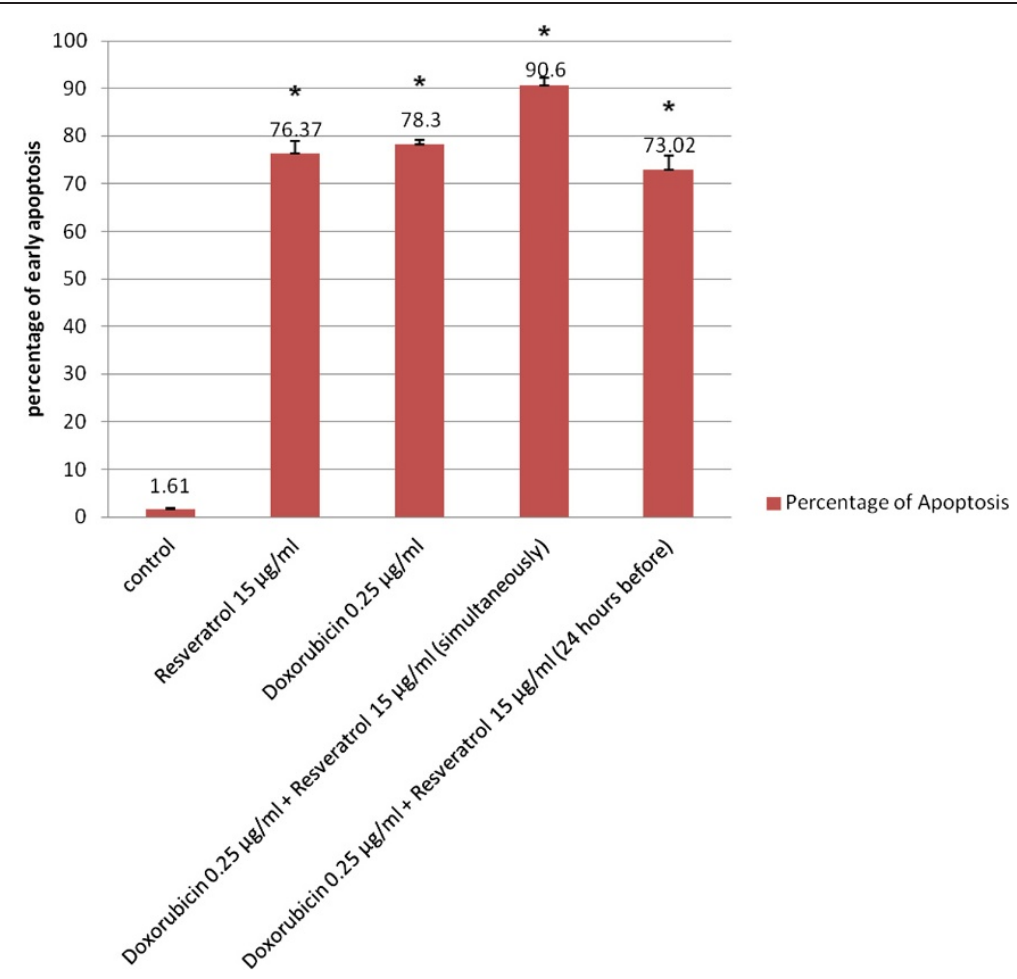

Figure 2 Effect of $0.25 \mu \mathbf{g} / \mathbf{m l}$ DOX and/or RSVL on apoptosis induction in MCF-7 cells. Apoptosis was analyzed after $48 \mathrm{~h}$ of exposure to drugs. Each point is the mean \pm S.E.M of two experiments each one in duplicate. ${ }^{*}$ Significantly different from control at P-value $<0.05$.

DOX $(0.25 \mu \mathrm{g} / \mathrm{ml})$ with $15 \mu \mathrm{g} / \mathrm{ml}$ RSVL 24 h before DOX also showed an increase in the percentages of cells in $\mathrm{G}_{0}$ phase compared with $G_{1}$ phase cells but the increase was less than that observed after the simultaneous trearment. The cell accumulation percentages at $G_{0}$ phase were $58.61 \%$ for cells treated with $15 \mu \mathrm{g} / \mathrm{ml}$ of RSVL followed by $0.25 \mu \mathrm{g} / \mathrm{ml}$ DOX after $24 \mathrm{~h}$, (Figure 4).

\section{Effect of RSVL on doxorubicin cellular accumulation}

MCF-7 cells were treated with different concentrations of DOX $(0.125,0.25$ and $0.5 \mu \mathrm{g} / \mathrm{ml})$ in the presence or absence of $15 \mu \mathrm{g} / \mathrm{ml}$ RSVL given simultaneously or $24 \mathrm{~h}$ before DOX.

Table 3 showed DOX cellular uptake concentrations after treatment with DOX alone, DOX+RSVL (simultaneously)

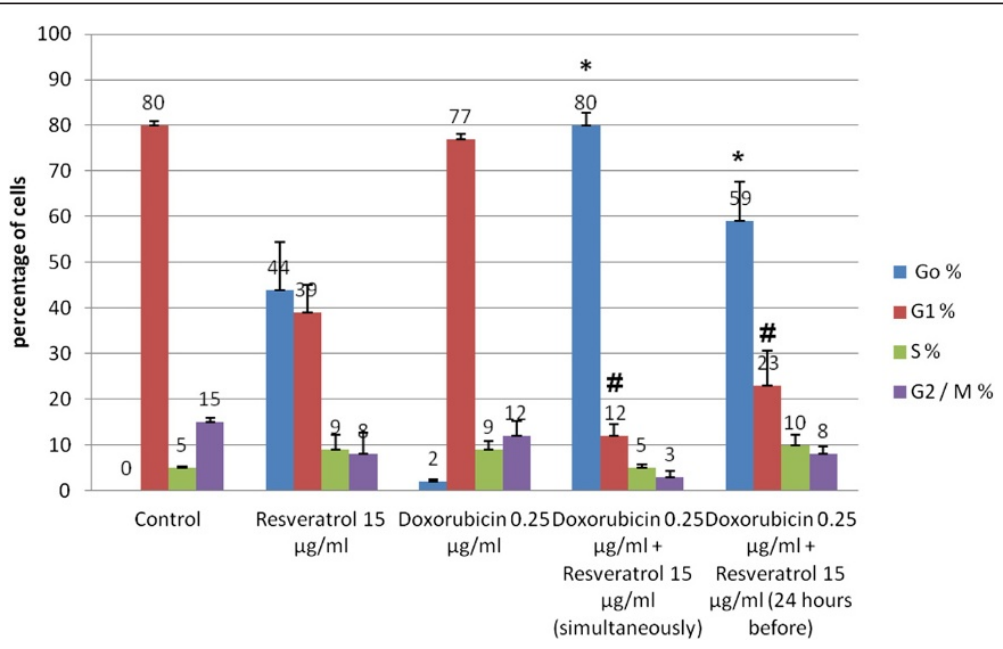

Figure 3 Effect of $0.25 \mu \mathrm{g} / \mathrm{ml} \mathrm{DOX}$ and/or RSVL on cell cycle phase distribution of MCF-7 cells. Cell cycle distribution was analyzed after $48 \mathrm{~h}$ of exposure to drugs by staining with propidium iodide (PI). Each point is the mean \pm S.E.M of two experiments each one in duplicate. * Significantly different from the corresponding DOX-induced Go arrest at P-value $<0.05$. \# Significantly different from the corresponding DOXinduced G1 arrest at P-value $<0.05$. 


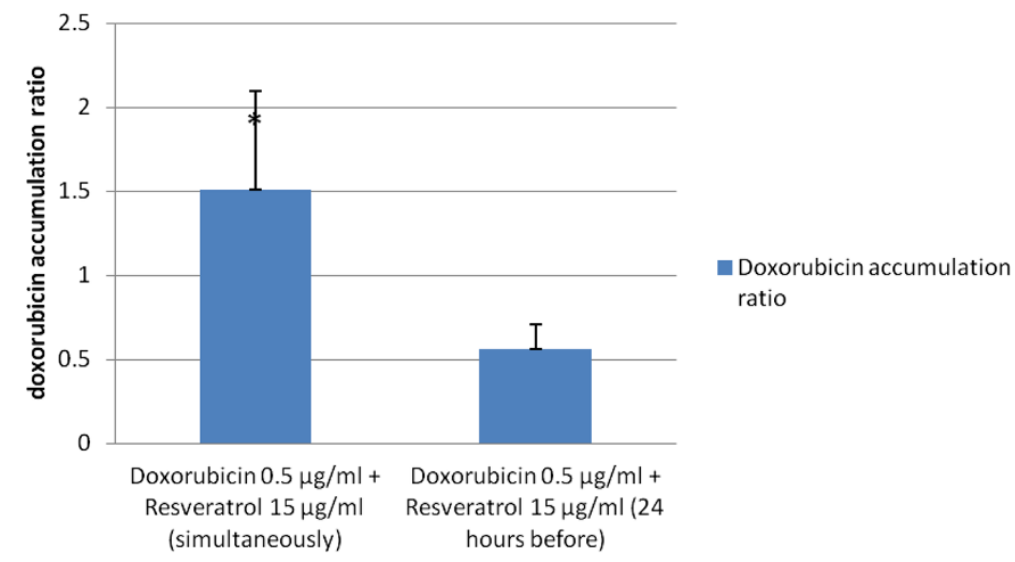

Figure 4 Effect of RSVL supplied either simultaneously or $24 \mathrm{~h}$ before $0.5 \mu \mathrm{g} / \mathrm{ml}$ DOX on DOX cellular uptake in MCF-7 cells. DOX accumulation ratio was calculated after $48 \mathrm{~h}$ of exposure to drugs as seen in materials and methods (3.2.4.3). Each data is the mean \pm S.E.M of two experiments each one in duplicate. * Significantly different from DOX+RSVL (24 h before) at P-value $<0.05$.

and DOX+RSVL (RSVL supplied $24 \mathrm{~h}$ before DOX). DOX cellular uptake concentrations were $0.022,0.027$ and 0.041 $\mu \mathrm{g} / 6 \times$ cells in MCF-7 cells treated with $0.125,0.25$ and 0.5 $\mu \mathrm{g} / \mathrm{ml} \mathrm{DOX}$, respectively.

Table 3 and Figure 4 showed that RSVL treatment simultaneously with DOX increased its cellular accumulation gradually. The accumulation ratio was 1.58 when cells treated with $0.5 \mu \mathrm{g} / \mathrm{ml}$ DOX simultaneously with $15 \mu \mathrm{g} / \mathrm{ml} \mathrm{RSVL}$, respectively.

Contrary to the above results, in MCF-7 cells that were pre-treated with $15 \mu \mathrm{g} / \mathrm{ml}$ RSVL $24 \mathrm{~h}$ before the cellular accumulation ratio was 0.58 compared with 1.58 when cells treated with $0.5 \mu \mathrm{g} / \mathrm{ml}$ DOX after $24 \mathrm{~h}$ of treatment with $15 \mu \mathrm{g} / \mathrm{ml}$ (Figure 4).

\section{Discussion}

Doxorubicin is the most widely used drug in the treatment of a variety of human neoplasms, However, with the increasing use of DOX, acute as well as chronic cumulative dose-dependent cardiomyopathy has been recognized as the major limiting factor for DOX chemotherapy $[12,13]$. Therefore, in this study we investigated the modulatory effect of the natural polyphenolic compound, RSVL on DOX cytotoxicity in MCF-7 human breast cancer cell line.

Table 3 Effect of RSVL treatment on the cellular uptake of DOX in MCF-7 cells

\begin{tabular}{lccc}
\hline Treatment & \multicolumn{2}{c}{ DOX Concentration $(\boldsymbol{\mu g} / \mathbf{1 0 6} \times$ cells) } \\
\cline { 2 - 4 } & Alone & $\begin{array}{c}\text { Simultaneously } \\
\text { with RSVL }\end{array}$ & $\begin{array}{c}\text { RSVL } \mathbf{2 4} \mathbf{~} \\
\text { before }\end{array}$ \\
\hline DOX $(\mathbf{0 . 5} \boldsymbol{\mu g} / \mathbf{m l})$ & $0.041 \pm 0.008$ & $0.062^{\mathbf{a}} \pm 0.011$ & $0.023 \pm 0.001$ \\
\hline DOX $(\mathbf{0 . 2 5} \boldsymbol{\mu g} / \mathbf{m l})$ & $0.027 \pm 0.004$ & $0.031 \pm 0.005$ & $0.024 \pm 0.001$ \\
\hline DOX $(\mathbf{0 . 1 2 5} \boldsymbol{\mu g} / \mathbf{m l})$ & $0.022 \pm 0.004$ & $0.021 \pm 0.004$ & $0.013 \pm 0.002$ \\
\hline
\end{tabular}

Each data is the mean \pm S.E.M of two experiments each one in duplicate. ${ }^{\text {a }}$ Significantly different from DOX at P-value $<0.05$.
Treatment of MCF-7 cells with different DOX doses alone was observed to be cytotoxic to the cells. The cytotoxicity of DOX has been confirmed by the results of induction of apoptosis and cell cycle progression, where $0.25 \mu \mathrm{g} / \mathrm{ml}$ DOX induced 49 -fold increase in early apoptotis and 2-fold increase in arrest of the cells in $\mathrm{S}$ phase in comparison with control cells.

Similar results was obtained following single treatment of DOX in MCF-7 cells [14]. In support of the importance of cell-cycle arrest to DOX cytotoxicity, it has been found that P388 leukemia cells synchronized in $\mathrm{S}$ and $\mathrm{G}_{2} / \mathrm{M}$ phases were more sensitive to DOX than cells in $\mathrm{G}_{1}$ phase [15]. Our results, have further confirmed the fact that anthracyclines are mostly active on proliferating cells in $\mathrm{S}$ and $\mathrm{G}_{2} / \mathrm{M}$ phases due to the maximal expression of their target enzyme TOPO II at these phases $[16,17]$.

Resveratrol is known to have both cardioprotective and antitumor activities [7,18] and it can attenuate DOX-induced early cellular damage in cancer patients [19]. Thus RSVL is a perfect candidate to be used as a sensitizing agent to modulate the cytotoxic effect of DOX against the growth of breast cancer cells. We also observed that, MCF-7 cells treated with RSVL alone showed high increase in early apoptosis, S-phase and in $\mathrm{G}_{0}$ phase (Figures 2 and 3). Resveratrol has previously been shown to induce dose-dependent cell cycle arrest, growth inhibition or apoptosis in several human cancer cell lines [20]. Resveratrol apoptosis induction effect in tumor cell line from different origins was shown to be through a lot of different regulatory mechanisms [21,22]. Previous studies on the effects of RSVL on the cell cycle of many cell lines including MCF-7 cells, demonstrated the ability of RSVL to block the $S-G_{2}$ transition resulting in a concentration-dependent accumulation of cells in $S$ or $G_{1}$ phase which may be due to inhibition of the 
enzymes used for DNA replication such as ribonucleotide reductase [20,23-25]. Other mechanisms that could explain RSVL-induced S phase arrest is the increase expression of p53, a tumor suppressor protein [26], the increase expression of positive $G_{1} / S$ regulators, such as cyclin D1 and cyclin E which are responsible for S phase entry [27], depletion of survivin, an inhibitor of apoptosis protein [7]. Resveratrol-induced S phase arrest would eventually lead to apoptotic death as indicated by the very high increase in $\mathrm{G}_{0}$ phase arrest (Figure 3).

Treatment with $15 \mu \mathrm{g} / \mathrm{ml}$ RSVL supplied simultaneously with different DOX concentrations enhanced the cytotoxic effect of DOX significantly. There was a 7.4fold decrease in IC50 in cells treated with DOX and RSVL simultaneously as compared with DOX treated cells (Table 2). To gain further insight into the interaction mechanisms between DOX and RSVL, apoptosis assay, flow cytometric DNA analysis and DOX cellular uptake assay were performed. Apoptosis assay showed a small increase of the early apoptotic cell percentages in the simultaneous treated cells as compared with DOX treated group. The smaller DOX dose used simultaneously with RSVL showed a stronger increase in apoptosis as compared with DOX treated group (Figure 2). Furthermore, flow cytometric analysis revealed that simultaneous treatment of DOX with RSVL induced preferential cell arrest at $G_{0}$, there were 41 -fold increase in percentages of $G_{0}$ phase arrest for treated cells (Figure 3). Several studies have reported that RSVL molecular mechanisms of sensitization for drug induced apoptosis involved cell cycle arrest in S phase [27,28], which has been used as a strategy to increase drug incorporation into cells. Thus, the cooperative effect of RSVL and the cell cycle-dependent drug DOX may result from RSVLinduced cell cycle arrest in $\mathrm{S}$ phase, thereby exposing a higher proportion of tumor cell population to DOX, therefore, more cells will undergo apoptosis and leave the cycle to enter the apoptotic $G_{0}$ phase.

These findings have been further confirmed by the observed increased in DOX cellular uptake after the simultaneous treatment with RSVL, which was in a dose dependent manner. There were an increase in DOX accumulation ratios for cells treated with DOX and RSVL, (Figure 4). This implies that, RSVL not only exposed higher proportion of MCF-7 cells to DOX by inducing cell cycle arrest in S phase but it also increased the DOX concentration available inside the cells. The increase in DOX cellular uptake inside the MCF-7 cells may be explained based on the inhibition of P-glycoprotein and multidrug resistance (MDR) [29] that plays very important role in the absorption, distribution, and elimination of DOX, and thus determines its efficacy and toxicity $[29,30]$. Surprisingly our results showed that when RSVL was given prior to DOX, although it was more cytotoxic against the growth of MCF-7 cells, we noticed slight inhibition of DOX-induced apoptosis, less percentage of cells arrest in $\mathrm{G}_{0}$ and decreased DOX cellular uptake into the cells compared with simultaneous treatment with DOX and RSVL.

The decrease of DOX cellular uptake in MCF-7 cells and the arrest of cells in $\mathrm{S}$ phase suggest that the enhanced growth inhibitory effects observed after the sequential RSVL and DOX treatment may not be caused by the synergism between DOX and RSVL or by the increased DOX cellular uptake, but this may be caused by the cytotoxic activity of RSVL itself $[20,27]$.

Recently (2012), RSVL was found to reduce the intracellular accumulation of rhodamine 123 in colon cancer cell line suggesting that RSVL enhances the activity of Pglycoprotein [31]. These conflicting findings could be explained on the following basis: MDR can be acquired after initial exposure to the anticancer drugs [32]. In addition several studies have found that some of the well known P-glycoprotein antagonists such as verapamil and cyclosporine A can induce P-glycoprotein expression in colon carcinoma cells [33]. It is important to note that the time needed for expression and inhibition of P-glycoprotein by their antagonists is controversial. Therefore, based on our results we can say that RSVL antagonizes or inhibits P-glycoprotein when it is given simultaneously with DOX thereby causing an increase in DOX cellular uptake [29]. However, when it is given $24 \mathrm{~h}$ before DOX it enhances the P-glycoprotein expression. The $24 \mathrm{~h}$ period between RSVL and DOX is considered as an intial exposure that will enhance the expression of P glycoprotein and thereby MDR that will lead to the decrease in DOX cellular uptake. Further studies are needed to investigate how different sequence of treatment of RSVL and DOX could affect the Pglycoprotein activity and hence by the DOX intracellular accumulation in MCF-7 cells.

\section{Competing interests}

The authors declare that they have no competing interests.

\section{Authors' contribution}

Abdel-Moneim, Zohir, sameer and Hadeel sharing in experimental work and writing the manuscript Mohamed Elshal did the flow cytometric analysis. All authors read and approved the final manuscript.

\section{Acknowledgments}

This project was funded by the Deanship of Scientific Research (DSR), King Abdulaziz University, Jeddah, under grants no. (1432/140/370).The authors, therefore, acknowledge with thanks DSR and Financial support.The technical assistance of Miss Mashael Abdulmohsin is highly acknowledged.

\section{Author details}

'Department of Pharmacology, Faculty of Medicine, King Abdul-Aziz University, Jeddah, Saudi Arabia. ${ }^{2}$ Depatment of Biochemistry, Faculty of Science, King Abdul-Aziz University, Jeddah, Saudi Arabia.

Received: 27 September 2012 Accepted: 8 October 2012

Published: 16 November 2012 


\section{References}

1. Najjar $\mathrm{H}$, Easson A: Age at diagnosis of breast cancer in Arab nations. Int J Surg 2010, 8(6):448-452.

2. Weiss RB: The anthracyclines: will we ever find a better doxorubicin? Semin Oncol 1992, 19(6):670-686.

3. Lefrak EA, Pitha J, Rosenheim S, Gottlieb JA: A clinicopathologic analysis of adriamycin cardiotoxicity. Cancer 1973, 32(2):302-314

4. Goswami SK, Das DK: Resveratrol and chemoprevention. Cancer Lett 2009, 284(1):1-6.

5. Cal C, Garban H, Jazirehi A, Yeh C, Mizutani Y, Bonavida B: Resveratrol and cancer: chemoprevention, apoptosis, and chemo-immunosensitizing activities. Curr Med Chem Anticancer Agents 2003, 3(2):77-93.

6. Athar M, Back JH, Tang X, Kim KH, Kopelovich L, Bickers DR, Kim AL: Resveratrol: a review of preclinical studies for human cancer prevention. Toxicol Appl Pharmacol 2007, 224(3):274-283

7. Aggarwal BB, Bhardwaj A, Aggarwal RS, Seeram NP, Shishodia S, Takada Y: Role of resveratrol in prevention and therapy of cancer: preclinical and clinical studies. Anticancer Res 2004, 24(5A):2783-2840.

8. Skehan P, Storeng R, Scudiero D, Monks A, McMahon J, Vistica D, Warren JT, Bokesch H, Kenney S, Boyd MR: New colorimetric cytotoxicity assay for anticancer-drug screening. J Natl Cancer Inst 1990, 82(13):1107-1112.

9. Van Engeland M, Nieland LJ, Ramaekerss FC, Schutte B, Reutelingsperger CP: Annexin V-affinity assay: a review on an apoptosis detection system based on phosphatidylserine exposure. Cytometry 1998, 31(1):1-9.

10. Pozarowski P, Darzynkiewicz Z: Analysis of Cell Cycle by Flow Cytometry Methods. Mol.Biol 2004, 281:301-311.

11. Kitagawa S, Nabekura T, Kamiyama S: Inhibition of P-glycoprotein function by tea catechins in KB-C2 cells. J Pharm Pharmacol 2004, 56(8):1001-1005.

12. Buzadar AS, Marcus TL, Smith TL, Blumenschein GR: Early and delayed clinical cardio toxicity of doxorubicin. Cancer 1981, 55(12):2761-2765.

13. Kantrowitz NE, Bristow MR: Cardiotoxicity of antitumor agents. Prog Cardiovasc Dis 1984, 27(3):195-200.

14. Meiyanto E, Hermawan A, Junedi S, Fitriasari A, Susidarti RA: Nobile tin increased cytotoxic activity Of doxorubicin on Mcf-7 cells but not on T47d cells. IJOP 2011, 3(1):129-137.

15. Ling YH, El-Naggar AK, Priebe W, Perez-Soler R: Cell cycle dependent cytotoxicity, G2-M phase arrest, and disruption of p34cdc2/cyclin B1 activity induced by doxorubicin in synchronized p388 cells. Mol Pharmacol 1996, 49(5):832-841.

16. Ormrod D, Holm K, Goa K, Spencer C: Epirubicin: a review of its efficacy as adjuvant therapy and in the treatment of metastatic disease in breast cancer. Drugs Aging 1999, 15(5):389-416.

17. Stacey D, Hitomi M, Chen G: Infleunce of cell cycle and oncogene activity upon topoisomerase lla expression and drug toxicity. Mol Cell Biol 2000, 20(24):9127-9130

18. Juan ME, Vinardell MP, Planas JM: The daily oral administration of highdoses of trans-resveratrol to rats for 28 days is not harmful. J Nutr 2002, 132(2):257-260.

19. Oktem G, Uysal A, Oral O, Sezer ED, Olukman M, Erol A, Akgur SA, Bilir A: Resveratrol attenuates doxorubicin-induced cellular damage by modulating nitric oxide and apoptosis. Exp Toxicol Pathol 2012, 64(5):471-479

20. Gusman J, Malonne H, Atassi G: A reappraisal of the potential chemopreventive and chemotherapeutic properties of resveratrol. Carcinogenesis 2001, 22(8):1111-1117.

21. Ahmad N, Adhami VM, Afaq F, Feyes DK, Mukhtar H: Resveratrol causes WAF-1/p21-mediated G(1)-phase arrest of cell cycle and Induction of apoptosis in human epidermoid carcinoma A431 cells. Clin Cancer Res 2001, 7(5):1466-1473.

22. Dörrie J, Gerauer H, Wachter Y, Zunino SJ: Resveratrol induces extensive apoptosis by depolarizing mitochondrial membranes and activating caspase 9 in acute lymphoblastic leukemia cells. Cancer Res 2001, 61(12):4731-4739.

23. Ragione FD, Cucciolla V, Borriello A, Pietra VD, Racioppi L, Soldati G, Manna C, Galletti P, Zappia V: Resveratrol arrests the cell division cycle at S/G2 phase transition. Biochem Biophys Res Commun 1998, 250(1):53-58.

24. Bernhard D, Tinhofer I, Tonko M, Hubl H, Ausserlechner MJ, Greil R, Kofler R, Csordas A: Resveratrol causes arrest in the S-phase prior to Fas independent apoptosis in CEM-C7H2 acute leukemia cells. Cell Death Differ 2000, 7(9):834-842
25. Joe AK, Liu H, Suzui M, Vural ME, Xiao D, Weinstein IB: Resveratrol induces growth inhibition, S-phase arrest, apoptosis, and changes in biomarker expression in several human cancer cell lines, Clin. Cancer Res 2002, 8:893-903

26. Huang C, Ma WY, Goranson A, Dong Z: Resveratrol suppresses cell transformation and induces apoptosis through a p53-dependent pathway. Carcinogenesis, Lond 1999, 20(2):237-242.

27. Pozo-Guisado E, Alvarez-Barrientos A, Mulero-Navarro S, Santiago-Josefat B, Fernandez-Salguero PM: The antiproliferative activity of resveratrol results in apoptosis in MCF-7 but not in MDA-MB-231 human breast cancer cells: cell-specific alteration of the cell cycle. Biochem Pharmacol 2002, 64(9):1375-1386.

28. Gupta SC, Kannappanm R, Reuter S, Kim JH, Aggarwal BB: Chemosensitization of tumors by resveratrol. Ann N Y Acad Sci 2011 1215:150-160.

29. Al-Abd AM, Mahmoud AM, El-Sherbiny GA, El-Moselhy MA, Nofal SM, El-Latif HA, El-Eraky WI, El-Shemy HA: Resveratrol enhances the cytotoxic profile of docetaxel and doxorubicin in solid tumour cell lines in vitro. Cell Prolif 2011, 44(6):591-601.

30. KIM HS, Kim TH: Resveratrol enhances the sensitivity of doxorubicin mediated cell proliferation, invasion, and migration in human breast cancer cell lines. 2010, http://www.fasebj.org/cgi/content/ meeting_abstract/24/1_MeetingAbstracts/964.10

31. Yang SY, Tsai SY, Hou SC, Chao PDL: Inductive modulation on Pglycoprotein and cytochrome3A by resveratrol, a constituent of grapes. Food Chemistry 2012, 133(3):683-688.

32. Chaudhary $P$, Roninson I: Induction of multi-drug resistance in human cells by transient exposure to different chemotherapeutic drugs. J Natl Cancer Inst 1993, 85(8):632-639.

33. Herzog C, Tsokos M, Bates S, Fojo A: Increased mdr-1/P Glycoproteinexpression after treatment of human colon carcinoma cells with P Glycoprotein antagonists. J Biol Chem 1993, 268(4):2946-2952.

doi:10.1186/1475-2867-12-47

Cite this article as: Osman et al: Modulation of doxorubicin cytotoxicity by resveratrol in a human breast cancer cell line. Cancer Cell International 2012 12:47.

\section{Submit your next manuscript to BioMed Central and take full advantage of:}

- Convenient online submission

- Thorough peer review

- No space constraints or color figure charges

- Immediate publication on acceptance

- Inclusion in PubMed, CAS, Scopus and Google Scholar

- Research which is freely available for redistribution 